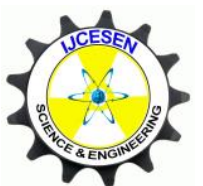

Copyright (C) IJCESEN
International Journal of Computational and

Experimental $\boldsymbol{S}$ cience and Engineering

(IJCESEN)

Vol. 4-No.3 (2018) pp. 43-50

http://dergipark.gov.tr/ijcesen

Research Article

\title{
Thermal Analysis of a Zirconium Dioxide Coated Aluminum Alloy Piston
}

\author{
Murat OZSOY $^{1 *}$, Ismet TIKIZ ${ }^{2}$, Huseyin PEHLIVAN ${ }^{1}$ \\ ${ }^{1}$ Sakarya University, Engineering Faculty, Mechanical Engineering Department, Sakarya, TURKEY \\ ${ }^{2}$ Kurklareli University, Engineering Faculty, Mechanical Engineering Department, Kırklareli, TURKEY \\ * Corresponding Author : ozsoy@ sakarya.edu.tr \\ ORCID: 0000-0003-2400-5212
}

\section{$\underline{\text { Article Info: }}$}

DOI: $10.22399 /$ ijcesen. 479222

Received : 06 November 2018

Accepted : 26 November 2018

\section{Keywords}

Thermal analysis

Finite element method

Thermal barrier coating

Aluminum alloy piston

\begin{abstract}
:
Performance and operating costs are the most important factors in internal combustion engines. It is one of the most commonly used methods to coat pistons with advanced technological ceramic materials in order to improve performance and fatigue life in internal combustion engines. In this study, changes in temperature and heat flux were investigated in various thickness coatings made on a $2500 \mathrm{cc}$ turbo diesel engine piston. As bonding coat, $\mathrm{NiCrAl}$ was used in a thickness of $0.2 \mathrm{~mm}$, while $\mathrm{ZrO}_{2}$ (zirconium dioxide) was used in thicknesses of $0.2-0.4-0.6$ and $0.8 \mathrm{~mm}$ as thermal barrier coating material. The piston was modeled in PTC Creo parametric software and then transferred to ANSYS Workbench environment to create a mathematical model. Engineering calculations were also done using the finite element method. After the calculation, the temperatures at the depth of $5 \mathrm{~mm}$ from the combustion chamber upper surface, the binder layer upper surface, the thermal coating upper surface and the combustion chamber upper surface were compared. As a result, it was observed that the combustion chamber and the section at the depth of $5 \mathrm{~mm}$ from the combustion chamber had a temperature decrease of $13 \%$.
\end{abstract}

\section{Introduction}

Thermal barrier coatings (TBCs) are extensively applied to protect metallic components of aircraft engines in an aggressive environment for improving the engine efficiency by increasing operating temperatures [1]. The zirconia based materials got increasing interest in the thermal barrier coatings [2]. These ceramic coatings help increase the entry temperature, which translates to higher performance and efficiency of the engine. However, with an ever-increasing demand for higher operating temperatures, a failure mode related to interaction between the ceramic coatings and molten deposits significantly affects the durability of TBCs [3]. Thermal barrier coatings (TBCs) have been widely used to provide thermal protection for the hot-section metal components in advanced gas turbines and diesel engines to improve thermal efficiency and performances [13]. Currently, 6-8 wt. $\% \quad \mathrm{Y}_{2} \mathrm{O}_{3}$ stabilized zirconia (YSZ) is considered as a good choice for the ceramic top coat material due to its superior durability during thermal cycling [4].

Ramaswamy at al. [5] study involves the need and developmental efforts made via Computational Fluid Dynamics (CFD) to generate a model via ANSYS - Fluent simulation software that predicts the temperature gradient across Thermal Barrier Coatings of different type ceramics and coating thicknesses.

To determine the optimum coating thickness, Dudavera at all. [6] simulated the thermal state of the piston using ANSYS Multiphysics. In this study, motor tests of the pistons using the singlecylinder unit of a four-cylinder two-stroke engine. The coating was applied to the surface of the piston head on the combustion chamber side.

Bolek at al. [7], investigate thermal barriers composed of $\mathrm{ZrO}_{2}+20 \% \mathrm{Y}_{2} \mathrm{O}_{3}$ and $\beta-\mathrm{NiAl}$ intermetallic diffusion layers were fabricated on Inconel 713C. The numerical simulation of the real shape of the interface between the layers revealed 
that stress concentration zones occur not only at the peaks and valleys of the interface but also on the semi-flat surface in the midway between them.

Kumar at al. [8] has researched material structural forms. The analysis was carried out for $\mathrm{Al}-\mathrm{ZrO}_{2}$ combination with different volume fraction indices. A parametric study with different power-law indices, thickness ratios, aspect ratios, support conditions and load parameters on non-dimensional centroidal deflection had been performed.

Yerrennagoudaru and Manjunatha [9] designed conventional and modified piston in the Unigraphics software and the resulting flow field was analyzed for different piston configurations by using CFD software Fluent ANSYS-14.5. Compere temperature in conventional piston and modified piston, during analysis conventional piston means without ceramic and platinum coating, modified piston means with without ceramic and platinum coating and for these pistons Swirl ratio, Tumble ratio Y, Cross Tumble Ratio graphs has drawn.

Ma at al. [10] was investigated ultrasonic vibration was introduced to assist laser clad coatings, and the effect of ultrasonic vibration on the cross section morphology, microstructure evolution and dilution characteristics between coating and substrate. Thermal and structure finite element analysis has been employed to be informed the thermal stresses developed in $\mathrm{Al}_{2} \mathrm{O}_{3}-\mathrm{SG}, \mathrm{ZrO}_{2}-12 \% \mathrm{Si}+\mathrm{Al}$ and $\mathrm{ZrO}_{2^{-}}$ SG coatings subjected to thermal loading by Kocabicak at all. [11]. Systems with $0.4 \mathrm{~mm}$ coating thickness and $4 \mathrm{~mm}$ substrate material thickness were modelled. The finite element technique can be used to optimise the design and the processing of ceramic coatings.

Celik ve Sarikaya [12] were investigated the effect on residual stresses of porosity in $\mathrm{MgO}-\mathrm{ZrO}_{2}$ coatings on Al-Si alloy substrate. Thermal loads were applied to the model at the temperature of $550^{\circ} \mathrm{C}$ using finite element method. Finite element calculations demonstrated that the highest thermal shock resistance was reached in the coating system with $7.5 \%$ small size sphere shape and uniformly distributed porosity. The coating with above $7.5 \%$ porosity had maximum values in radial, axial and shear stresses.

Taymaz at al. [13] studies the effect of surface preparation techniques. Thermal and structural finite element analysis has been employed to analyse the level of stresses developed $\mathrm{Al}_{2} \mathrm{O}_{3}-\mathrm{SG}$, $\mathrm{ZrO}_{2}(12 \% \mathrm{Si}+\mathrm{Al})$ and $\mathrm{ZrO}_{2}-\mathrm{SG}$ coatings subjected to thermal loading. Nominal and shear stresses at the critical interface regions (film/interlayer/substrate) were obtained and compared. The results showed that the $\mathrm{ZrO}_{2}-\mathrm{SG}$ coatings have a higher thermal shock resistance than the $\mathrm{Al}_{2} \mathrm{O}_{3}-\mathrm{SG}$ and $\mathrm{ZrO}_{2}(12 \% \mathrm{Si}+\mathrm{Al})$ coating systems.

Thermal analysis evolution of $\mathrm{MgO}-\mathrm{ZrO}_{2} / \mathrm{NiCrAlY}$ coatings on $\mathrm{Ni}$ metal and AlSi alloy (LM13) substrates was studied by Sarikaya and Celik [14]. $\mathrm{MgO}-\mathrm{ZrO}_{2} / \mathrm{NiCrAlY}$ coatings were deposited on metallic substrates using an atmospheric plasma spray technique. Thermal loadings were applied to the model at the temperature range $800-1000{ }^{\circ} \mathrm{C}$ using finite element method. It was also found that the larger residual stresses were obtained with an increase of the coating thickness and interlayer bond coatings decreased residual stresses.

Mimaroglu at al. [15] employed coupled (thermal and structure) finite-element analysis to analyse the influences of porosity volume, size and distribution in $\mathrm{MgO} . \mathrm{ZrO}_{2}$-GG coating subjected to thermal loading. The results showed that the volume, size, location and distribution of the porosity have a significant influence on the level of the developed thermal stresses in the case of $\mathrm{MgO}_{\mathrm{ZrO}}$-GG coatings the optimum low-level stresses are developed with $7 \%$ small-size uniformlydistributed porosity allocated far away from the coating surface.

Khor and $\mathrm{Gu}$ [16] prepared coatings with different thicknesses and coating layers for bond strength and thermal cycling resistance tests. They were studied the microstructure, micro hardness, density, elastic modulus, thermal conductivity/diffusivity and coefficient of thermal expansion. The $8 \mathrm{wt} . \%$ $\mathrm{Y}_{2} \mathrm{O}_{3}$ stabilized $\mathrm{ZrO}_{2}$ and NiCoCrAlY powders were used for the FGM coatings. The thermal cycling life of five-layer FGM coating is five times higher than that of the duplex coating which can be indicated from the FEA results.

Finite element code in ANSYS has been employed to analysis fracture in ceramic coatings subjected to thermal loading by Mimaroglu at all. [17].

Hypothetical material properties have been considered as material data for coupled (thermal and structure) finite element analysis and evaluated the stress intensity factors in different coatings. The results showed that the shorter the crack length and the thinner the coating, the sounder the coatings. Furthermore, coatings representing a wide range of thermal and mechanical properties have a close normalized stress intensity factor values. It is also concluded that the finite element technique can be used to optimize the design and the processing of ceramic coatings

As a result of the literature review made above, there is an increasing number of experimental and numerical studies on the thermal analysis of pistons. Generally, although bond materials were the same, different types of coating materials were 
used. In this study, the temperature distribution was examined for the original model and thermally coated model with four different thicknesses.

\section{Geometric and Mathematical Modelling of the Piston}

Geometric model of the piston body is modelled as a solid model at PTC Creo Parametric software. After modelling the piston body, first a $0.2 \mathrm{~mm}$ binding layer then thermal barrier coats with thicknesses of $0.2 \mathrm{~mm}-0.4 \mathrm{~mm}-0.6 \mathrm{~mm}$ and $0.8 \mathrm{~mm}$ modelled. Then for each thermal barrier coat a new assembly modelled, at last for finite element analyses four types of geometric models created. The Figure1 shows information about the properties of the geometric models.

$\mathrm{H}$ is a virtual path has 91 points on it for post processing. This path is created on the top surface of combustion chamber, $5 \mathrm{~mm}$ below the combustion chamber, on top surface of bond coat (binding layer) and on top surface of thermal coat.

After creating the geometric models of the original and thermal barrier coated pistons at PTC Creo Parametric, models were transferred to the Ansys Workbench software which is used for calculation by the finite element method. There are five types of models, first is original piston, second is $0.2 \mathrm{~mm}$ $\mathrm{NiCrAl}$ binding layer and $0.2 \mathrm{~mm} \mathrm{ZrO}_{2}$ thermal barrier coated, third is $0.2 \mathrm{~mm} \mathrm{NiCrAl}$ binding layer and $0.4 \mathrm{~mm} \mathrm{ZrO}_{2}$ thermal barrier coated, fourth is $0.2 \mathrm{~mm} \mathrm{NiCrAl}$ binding layer and $0.6 \mathrm{~mm}$ $\mathrm{ZrO}_{2}$ thermal barrier coated and last one is $0.2 \mathrm{~mm}$ $\mathrm{NiCrAl}$ binding layer and $0.8 \mathrm{~mm} \mathrm{ZrO}_{2}$ thermal barrier coated.

After creating and transferring the geometric model to the ANSYS Workbench environment, the most important step is creating the mesh. For creating a healthy mesh, mesh metrics-element quality method was used. The Element quality option provides a composite quality metric that ranges between 0 and 1 . This metric is based on the ratio of the volume to the sum of the square of the edge lengths for $2 \mathrm{D}$ quad/tri elements, or the square root of the cube of the sum of the square of the edge lengths for 3D elements. A value of 1 indicates a perfect cube or square while a value of 0 indicates that the element has a zero volume [18]. Table 1 shows the number of mesh, elements and also element quality of each mathematical model. All models have same bond coat as NiCrAl with a thickness of $0.2 \mathrm{~mm}$ so at table only thermal barrier coat included. Also a meshed model of one coated piston can be seen at Figure 2. During the meshing for binding layer and thermal barrier coat $0.1 \mathrm{~mm}$ element size of vertical direction used for a better mesh quality.
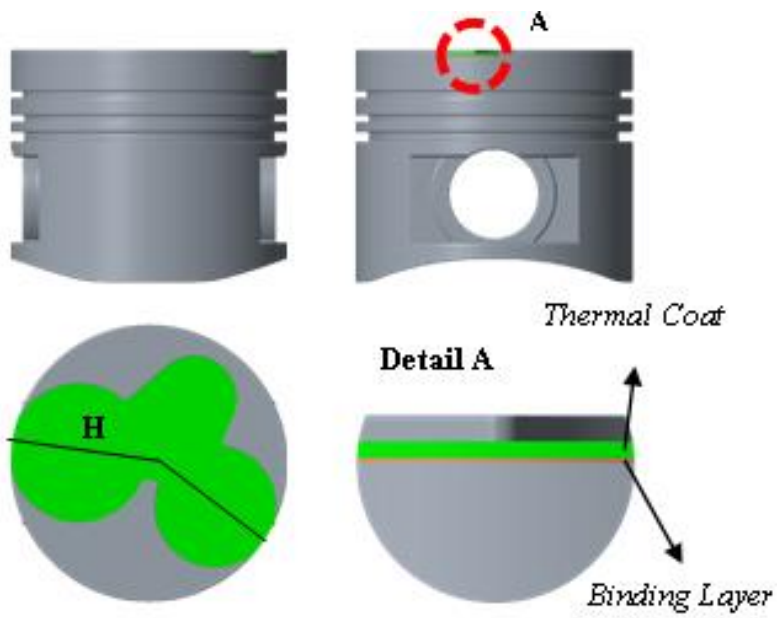

Figure 1. Geometric model of the thermal coated piston.

Table 1. Mesh statics-element quality of original and thermal barrier coated pistons

\begin{tabular}{|c|c|c|c|}
\hline \multirow{2}{*}{$\begin{array}{c}\text { Model } \\
\text { Properties }\end{array}$} & \multicolumn{2}{|c|}{ Mesh Statistics } & \multirow{2}{*}{$\begin{array}{c}\text { Element } \\
\text { Quality } \\
\text { (average) }\end{array}$} \\
\hline & $\begin{array}{c}\text { Node } \\
\text { Quantity }\end{array}$ & $\begin{array}{l}\text { Element } \\
\text { Quantity }\end{array}$ & \\
\hline Base Piston & 316197 & 208595 & 0.82 \\
\hline $0.2 \mathrm{~mm}$ Coated & 355475 & 215467 & 0.79 \\
\hline $0.4 \mathrm{~mm}$ Coated & 370882 & 219597 & 0.78 \\
\hline $0.6 \mathrm{~mm}$ Coated & 385398 & 223087 & 0.77 \\
\hline $0.8 \mathrm{~mm}$ Coated & 399914 & 226577 & 0.76 \\
\hline
\end{tabular}
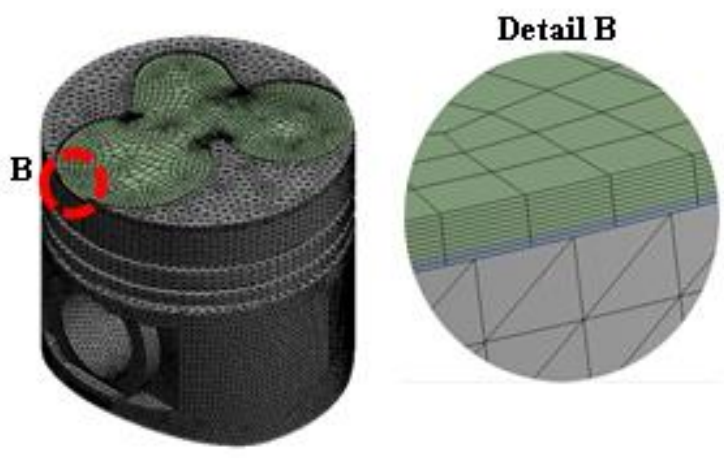

Figure 2. Meshed model of $0.2 \mathrm{~mm} \mathrm{NiCrAl} 0.8 \mathrm{~mm} \mathrm{ZrO}_{2}$

SOLID87 3-D 10-Node Tetrahedral Thermal Solid and SOLID90 3-D 20-Node Thermal Solid used as element types for meshing the volumes.

SOLID87 is well suited to model irregular meshes (such as produced from various CAD/CAM systems). The element has one degree of freedom, temperature, at each node. SOLID90 has 20 nodes with a single degree of freedom, temperature, at each node. The 20-node elements have compatible temperature shapes and are well suited to model curved boundaries [18]. 
After creating the mesh, material properties of the piston, binding layer and thermal coat was defined. Table 2 also shows the materials and their thermal properties used at finite element analyses.

Table 2. Thermal properties of the materials

\begin{tabular}{|c|c|c|c|}
\hline Material & $\begin{array}{c}\text { Thermal } \\
\text { conductivity } \\
{\left[\mathbf{W} / \mathbf{m}^{\circ} \mathbf{C}\right]}\end{array}$ & $\begin{array}{c}\text { Thermal } \\
\text { expansion } \\
\mathbf{1 0}-\mathbf{6}\left[\mathbf{1} /{ }^{\circ} \mathbf{C}\right]\end{array}$ & $\begin{array}{c}\text { Specific heat } \\
{\left[\mathbf{J} / \mathbf{k g}^{\circ} \mathbf{C}\right]}\end{array}$ \\
\hline $\mathrm{AlSi}$ & 237.5 & 21 & 960 \\
\hline $\mathrm{NiCrAl}$ & 16.1 & 12 & 764 \\
\hline $\mathrm{ZrO}_{2}$ & 3 & 11 & 460 \\
\hline
\end{tabular}

The next step of the analysis is defining the boundary conditions. For this mathematical model different boundary conditions were defined in seven regions [19]. Boundary conditions are listed below at Figure 3 and Table 3 below. After creating the mesh, defining material properties and boundary conditions, solutions were made for five different models.

Table 3. Properties of boundary conditions

\begin{tabular}{|c|c|c|}
\hline Region & $\begin{array}{c}\text { Film Coefficient } \\
\mathbf{W} / \mathbf{m m}^{2} \mathbf{C}\end{array}$ & $\begin{array}{c}\text { Ambient } \\
\text { Temperature }\end{array}{ }^{?} \mathbf{C}$ \\
\hline A & $8 \times 10^{-4}$ & 650 \\
\hline B & $2.3 \times 10^{-4}$ & 300 \\
\hline C & $6.25 \times 10^{-4}$ & 85 \\
\hline D & $1.15 \times 10^{-4}$ & 110 \\
\hline E & $1.91 \times 10^{-4}$ & 110 \\
\hline F & $7.17 \times 10^{-4}$ & 110 \\
\hline G & $625 \times 10^{-4}$ & 85 \\
\hline
\end{tabular}

\section{Results of the Analysis}

As previously mentioned, five different models were used for the solution. First is original piston without coat. The other four models are coated. The binder coating on all models is $0.2 \mathrm{~mm}$. Thermal coatings of four models are 0.2,0.4,0.6 and

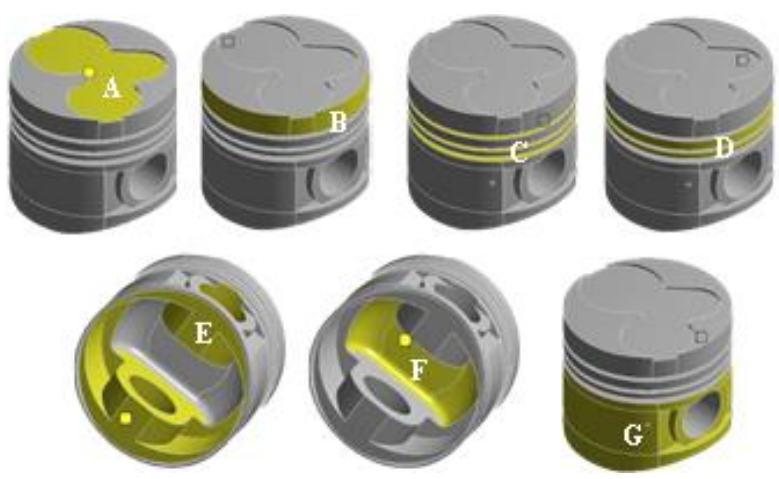

Figure 3. Boundary condition regions of the piston

$0.8 \mathrm{~mm} \mathrm{ZrO}_{2}$. All models were solved under the same boundary conditions. Finally, the responses of the models to the same boundary conditions were compared. Solutions were made in a computer with four core Intel Pentium I7-3770K @ 3.50 Hz and 16 $\mathrm{Gb}$ physical memory on windows 10 x64 platform. To compare the results, 4 paths were formed on the piston combustion chamber surface, $5 \mathrm{~mm}$ below the piston combustion chamber, above the binding coating and above the thermal coating. Detail of this path can be seen at figure $1(\mathrm{H})$. Likewise, the heat flux of all models is compared. Figure 4,5,6,7 shows temperature effect (TE) of termal barrier coating (TBC) on paths named $\mathrm{H}$ and temperature distrubition (TD) on several surfaces. Further, total heat flux of uncoated and $0.8 \mathrm{~mm} \mathrm{ZrO}_{2}$ coated pistons can be seen Figure 8. After solutions for each coating, results were examined according to the upper surface of the combustion chamber of the uncoated piston. Maximum temperature occured $242.3{ }^{\circ} \mathrm{C}$ at uncoated piston, $236.7{ }^{\circ} \mathrm{C}$ at $0.2 \mathrm{~mm}$ $\mathrm{ZrO}_{2}$ coated piston, $232.2{ }^{\circ} \mathrm{C}$ at $0.4 \mathrm{~mm} \mathrm{ZrO}_{2}$ coated piston, $227.95{ }^{\circ} \mathrm{C}$ at $0.6 \mathrm{~mm} \mathrm{ZrO}_{2}$ coated piston and $224.7{ }^{\circ} \mathrm{C}$ at $0.8 \mathrm{~mm} \mathrm{ZrO}_{2}$ coated piston. All results can be seen at Table 4 .

Table 4. Results of the finite element analysis

\begin{tabular}{|c|c|c|c|c|c|}
\hline Type & Uncoated & $\mathbf{0 . 2}$ mm coated & $\mathbf{0 . 4}$ mm coated & $\mathbf{0 . 6}$ mm coated & $\mathbf{0 . 8}$ mm coated \\
\hline Combustion chamber top surface max. temp. & 242.3 & 236.68 & 232.16 & 227.95 & 224.70 \\
\hline Binding layer top surface max. temp. & --- & 250.31 & 245.16 & 240.44 & 225.32 \\
\hline Thermal coating top surface max. temp. & --- & 264.97 & 277.79 & 290.67 & 299.38 \\
\hline Heat flux max & 0.83 & 1 & 0.95 & 1.22 & 1.44 \\
\hline Piston Section max. temp. & 236.4 & 230.63 & 226.27 & 222.27 & 219.31 \\
\hline
\end{tabular}



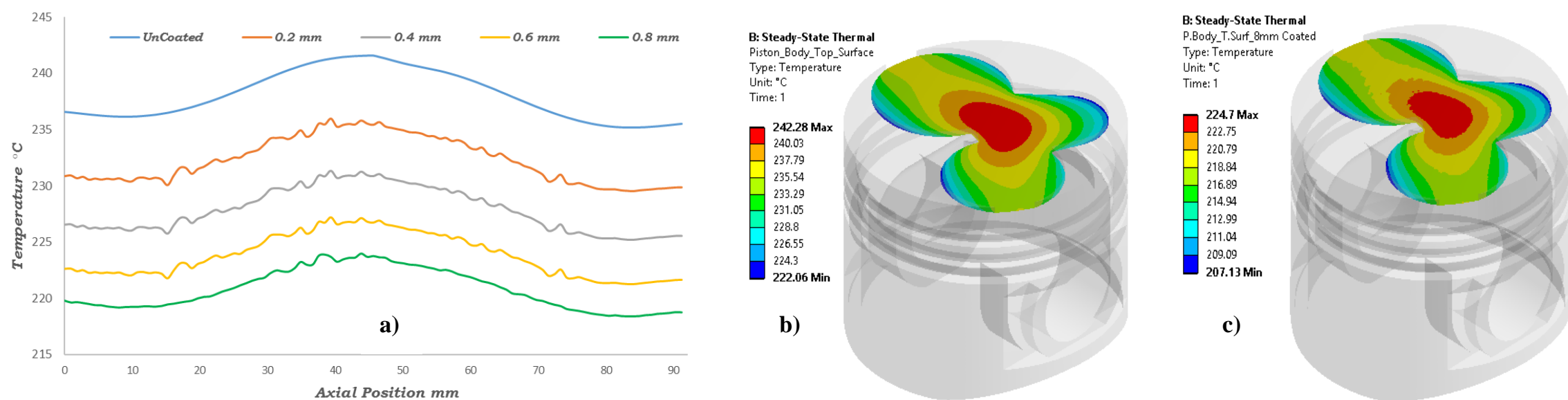

Figure 4. TE of TBC on piston combustion chamber top surface changing with distance (a), TD on combustion chamber of uncoated piston (b), TD on combustion chamber of uncoated piston with $0.8 \mathrm{~mm} \mathrm{ZrO}_{2}$ coated (c).
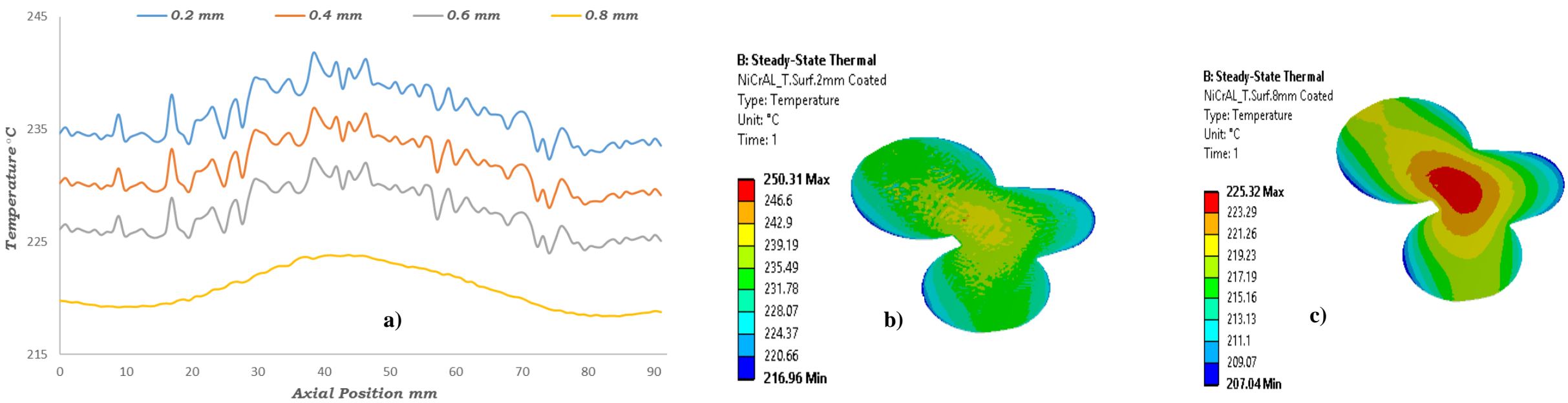

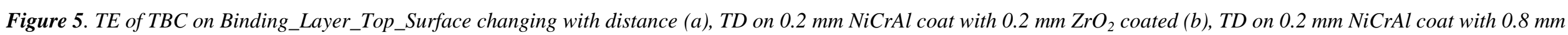
$\mathrm{ZrO}_{2}$ coated (c). 

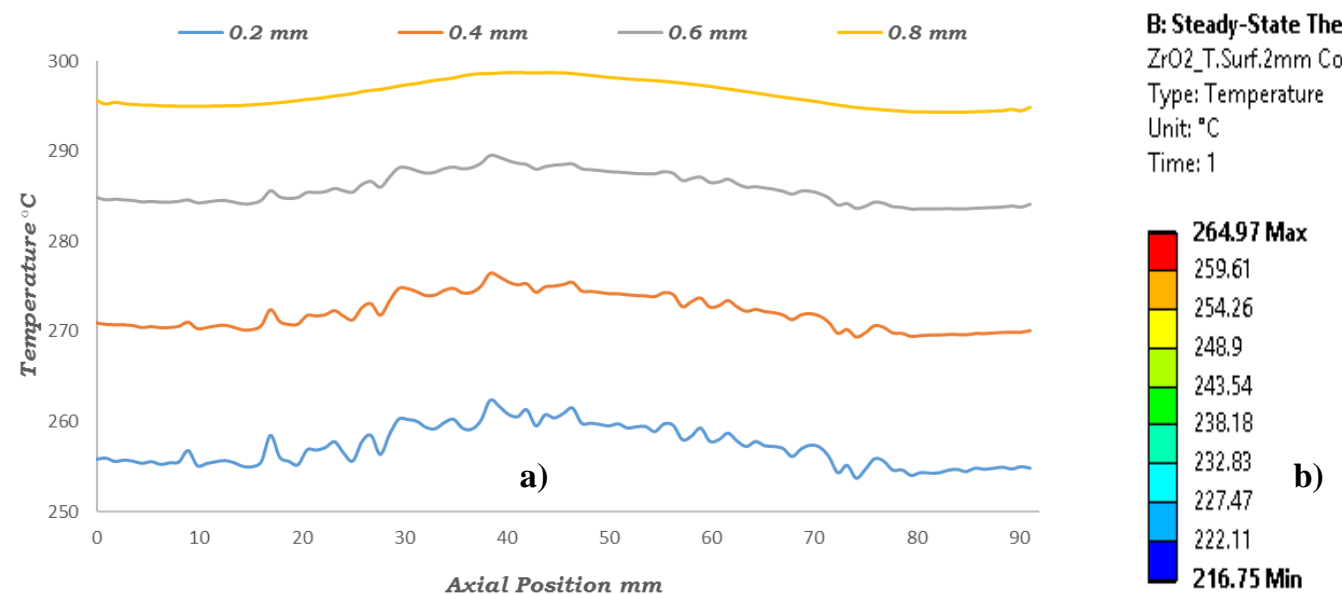

B: Steady-State Thermal ZrO2_. Turf.8mm Coate Type: Temperature Unit: ${ }^{\circ} \mathrm{C}$

Position mm

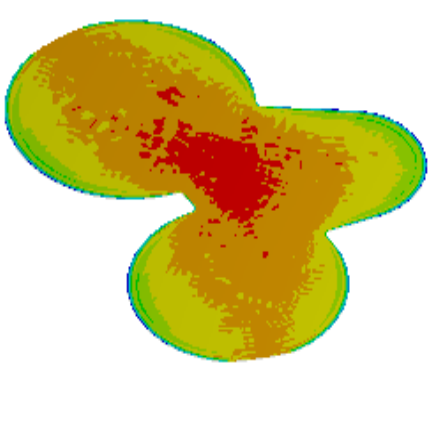

Figure 6. TE of TBC on Thermal_Coating_Top_Surface changing with distance (a), TD on $0.2 \mathrm{~mm} \mathrm{ZrO}_{2}$ coated (b), TD on 0.8 mm $\mathrm{ZrO} \mathrm{O}_{2}$ coated (c).
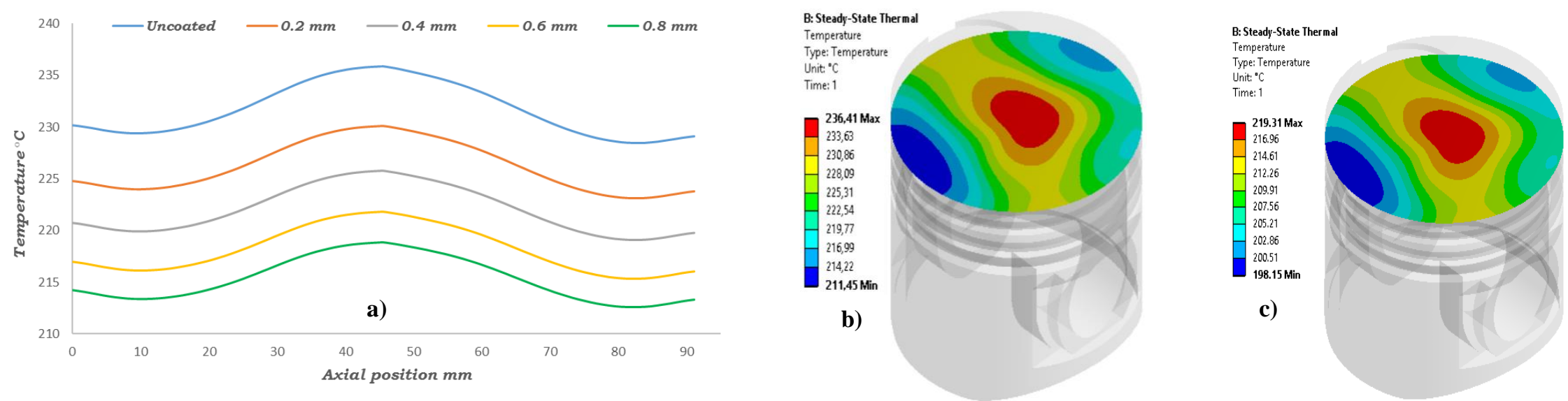

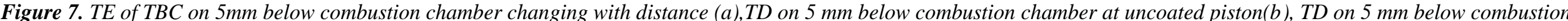
chamber at coated with $0.8 \mathrm{~mm} \mathrm{ZrO}_{2}(\mathrm{c})$. 

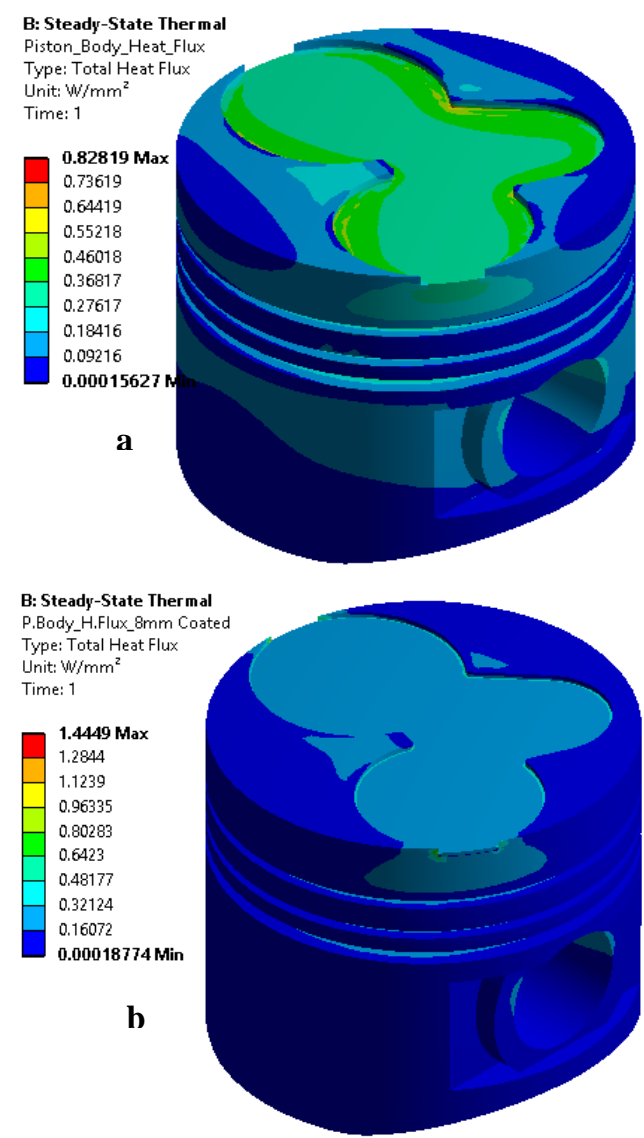

Figure 8. Total heat flux of uncoated piston a) and total heat flux of $0.8 \mathrm{~mm} \mathrm{ZrO}_{2}$ coated piston.

\section{Conclusion}

When the results were examined, in the terms of occurring maximum temperature at piston combustion chamber top surface level (Figure 4), it was observed that there was $7 \%$ decrease between the uncoated piston and $0.8 \mathrm{~mm} \mathrm{ZrO}_{2}$ coated piston. Looking at the results of the bond coat (binding layer), a temperature decrease of $10 \%$ is observed (Figure 5). The temperature increase as a value of $13 \%$ is observed on the top surface of the thermal coating (Figure 6).

This means that, the temperature is more confined on the thermal coating surface depending on the coating increasing.

At piston section level $(5 \mathrm{~mm}$ below the combustion chamber top surface of uncoated piston, Figure 7), a $7 \%$ temperature decrease seen. At the end of the study, as expected a reduction in temperature was achieved by the coating of combustion chamber top surface. The next step of this study is optimization of the binding and thermal coats. Also make an experimental study in terms of verify the results.

\section{References}

[1] Fu, Y., Shao, C., Cai, C., Wang, Y., Zhou, Y., Zhou, G., Temperature induced structure degradation of yttria-stabilized zirconia thermal barrier coatings, Surface \& Coatings Technology 351 (2018), 21-28 https://doi.org/10.1016/j.surfcoat.2018.07.057

[2] Khan, M., Zeng, Y., Lan, Z., Wang, Y., Reduced thermal conductivity of solid solution of $20 \% \mathrm{CeO}_{2}$ $+\mathrm{ZrO}_{2}$ and $8 \% \mathrm{Y}_{2} \mathrm{O}_{3}+\mathrm{ZrO}_{2}$ prepared by atmospheric plasma spray technique, Ceramics International, https://doi.org/10.1016/j.ceramint.2018.09.252

[3] Liu, H., Cai, J., Zhu, J., CMAS (CaO-MgO- $\mathrm{Al}_{2} \mathrm{O}_{3}-$ $\mathrm{SiO}_{2}$ ) resistance of $\mathrm{Y}_{2} \mathrm{O}_{3}$-stabilized $\mathrm{ZrO}_{2}$ thermal barrier coatings with $\mathrm{Pt}$ layers, Ceramics $\begin{array}{llll}\text { International } & 44 & \text { (2018), } & \text { 452-458 }\end{array}$ https://doi.org/10.1016/j.ceramint.2017.09.197

[4] Wang, J., Sun, J., Jing, Q., Liu, B., Zhang, H., Yu, Y., Yuan, J., Dong, S., Zhou, X., Cao, X., Phase stability and thermo-physical properties of $\mathrm{ZrO} 2-$ $\mathrm{CeO} 2-\mathrm{TiO} 2$ ceramics for thermal barrier coatings, Journal of the European Ceramic Society 38 (2018), 2841-2850, https://doi.org/10.1016/j.jeurceramsoc.2018.02.019

[5] Ramaswamy, P., Shankar V, Reghu V.R., Mathew, N., Manoj, K.S., A Model to Predict the Influence of Inconsistencies in Thermal Barrier Coating (TBC) Thicknesses in Pistons of IC Engines, Materials Today: Proceedings 5 (2018), 12623-12631 https://doi.org/10.1016/j.matpr.2018.02.245

[6]Dudareva, N.Y., Enikeev, R.D.a, Ivanov, V.Y., Thermal Protection of Internal Combustion Engines Pistons, Procedia Engineering 206 (2017) 1382-1387 https://doi.org/10.1016/j.proeng.2017.10.649

[7]Bolek, T., Sitek, R., Sienkiewicz, J., Dobosz, R., Mizera, J., Kobayashi, A., Kurzydlowski, K.J., Simulation of the influence of the interface roughness on the residual stresses induced in $\left(\mathrm{ZrO}_{2}+\mathrm{Y}_{2} \mathrm{O}_{3}\right)+\mathrm{NiAl}$-type composite coatings deposited on Inconel 713C, Vacuum 136 (2017), $221-228$ https://doi.org/10.1016/j.vacuum.2016.11.003

[8] Kumar, P.S.R., Kumar, P.N., Janardhana, G.R., Static Analysis of $\mathrm{Al}-\mathrm{ZrO}_{2} \mathrm{FG}$ Thick Plate Using Graded FEM, Materials Today: Proceedings 4 (2017), 81178126 https://doi.org/10.1016/j.matpr.2017.07.152

[9] Yerrennagoudaru, H., Manjunatha, K., Combustion analysis of modified inverted " $\mathrm{M}$ " type piston for diesel engine with platinum coating and without coating by using CFD, Materials Today: Proceedings 4 (2017), 2333-2340

https://doi.org/10.1016/j.matpr.2017.02.082

[10] Ma, G., Yan, S., Wu, D., Miao, Q., Liu, M., Niu, F., Microstructure evolution and mechanical properties of ultrasonic assisted laser clad yttria stabilized zirconia coating, Ceramics International 43 (2017), 9622-9629

https://doi.org/10.1016/j.ceramint.2017.04.103

[11] Kocabicak, U., Mimaroglu, A., Sarikaya, O., Mete, O.H., Comparison of the developed thermal stresses in $\mathrm{Al}_{2} \mathrm{O}_{3}-\mathrm{SG}, \mathrm{ZrO}_{2}-12 \% \mathrm{Si}+\mathrm{Al}$ and $\mathrm{ZrO}_{2}-\mathrm{SG}$ coating systems subjected to thermal loading, Materials and Design 20 (1999), 287-290

https://doi.org/10.1016/S0261-3069(99)00041-2 
[12] Celik, E., Sarikaya, O., The effect on residual stresses of porosity in plasma sprayed $\mathrm{MgO}-\mathrm{ZrO} 2$ coatings for an internal combustion diesel engine, Materials Science and Engineering A 379 (2004), $11-16$ https://doi.org/10.1016/j.msea.2003.12.019

[13] Taymaz, I., Mimaroglu, A., Avci, E., Ucar, V., Gur, M., Comparison of thermal stresses developed in $\mathrm{Al}_{2} \mathrm{O}_{3}-\mathrm{SG}, \quad \mathrm{ZrO}_{2}-(12 \% \mathrm{Si}+\mathrm{Al})$ and $\mathrm{ZrO}_{2}-\mathrm{SG}$ thermal barrier coating systems with $\mathrm{NiAl}, \mathrm{NiCrAlY}$ and NiCoCrAlY interlayer materials subjected to thermal loading,Surface and Coatings Technology 116-119 (1999), 690-693 https://doi.org/10.1016/S0257-8972(99)00121-8

[14] Sarikaya, O., Celik, E., Effects of residual stress on thickness and interlayer of thermal barrier ceramic $\mathrm{MgO}-\mathrm{ZrO}_{2}$ coatings on $\mathrm{Ni}$ and $\mathrm{AlSi}$ substrates using finite element method, Materials and Design 23 (2002), 645-650 https://doi.org/10.1016/S02613069(02)00047-X

[15] Mimaroglu, Kocabicak, U., A., Genc, S., Influence of porosity characteristics in $\mathrm{Mg} 0 . \mathrm{ZrO}_{2}-\mathrm{GG}$ coating subjected to thermal loading, Materials \& Design, 18(1997), 77-80 https://doi.org/10.1016/S0261$\underline{\text { 3069(97)00042-3 }}$

[16] Khor, K.A., Gu, Y.W., Effects of residual stress on the performance of plasma sprayed functionally graded $\mathrm{ZrO}_{2} / \mathrm{NiCoCrAlY}$ coatings, Materials Science and Engineering A277 (2000), 64-76 https://doi.org/10.1016/S0921-5093(99)00565-1

[17] Mimaroglu, A., Yenihayat, O.F. Avci, E., Numerical analysis of fracture in ceramic coatings subjected to thermal loading, Materials\&Design 17 (1996), 283-287

https://doi.org/10.1016/S0261-3069(97)00023-X

[18] ANSYS Workbench Help

[19] Buyukkaya, E., Thermal analysis of functionally graded coating AlSi alloy and steel pistons, Surface \& Coatings Technology 202 (2008) 3856-3865 https://doi.org/10.1016/j.surfcoat.2008.01.034 